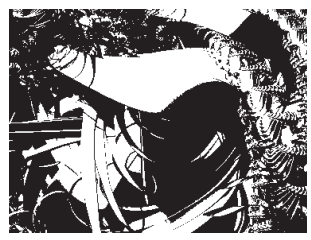

doi:10.5559/di.20.4.09

\title{
WAR VETERANS' QUALITY OF LIFE: THE IMPACT OF LIFETIME TRAUMATIC EXPERIENCES, PSYCHOLOGICAL AND PHYSICAL HEALTH-RELATED CHARACTERISTICS
}

Vesna ANTIČEVIĆ

Split University Hospital and School of Medicine, Split

Goran KARDUM

Faculty of Philosophy, Split

Dolores BRITVIĆ

Split University Hospital and School of Medicine, Split

UDK: 159.97-058.65(497.5) $355.087 .2(497.5): 616.89$

Izvorni znanstveni rad

Primlieno: 7. 6. 2010.

The purpose of this study was to evaluate the cross-sectional differences in self-reported psychological symptoms, life-time exposure to traumatic events, coping styles, personality traits and overall quality of life between the PTSD and non-PTSD Croatian War veterans. A total of 113 subjects within the three groups participated in the study (veterans with PTSD, non-PTSD veterans and controls). Veterans with PTSD assessed both combat experiences and exposure to other life-time traumatic events as extremely stressful, much more so than veterans without PTSD or control subjects. Scores among the non-PTSD veterans were similar to the control subjects, except on the M-PTSD scale, scale of psychosomatic symptoms and coping by avoidance. Intensity of PTSD, extraversion and active coping were individually significant in explaining the total QoL $(p<0.01)$. This study showed that veterans with PTSD became extremely vulnerable to lifetime stress events.

Keywords: PTSD, personality, quality of life

$\square \quad$ Vesna Antičević, Split University Hospital Center, University Department of Psychiatry, Regional Center for Psychotrauma, Šoltanska 1, 21000 Split, Croatia. 
The war in Croatia lasted from 1991 to 1996 and included frontal conflicts, exposure to shelling, and dangers of minefields. The majority of veterans were exposed to death and wounding of other war participants, as well as harsh weather conditions on the frontline.

Research shows that posttraumatic stress disorder (PTSD) is a common problem following violence, and that other emotional problems may be secondary to PTSD (Kilpatrick and Acierno, 2003; Johansen et al., 2007). War situation is certainly among the most difficult life situations, with the highest probability of going through multiple traumatic experiences. However, only 15-20\% of traumatized people develop PTSD (Ajduković et al., 2007). Most of the individuals who experience trauma may not meet full diagnostic criteria for PTSD, but may still have clinically significant symptoms that affect their psychological functioning, physical health, and social relations, which is often called partial PTSD. Although the majority of individuals exposed to trauma will not develop or maintain PTSD reactions, subthreshold reactions should not be overlooked (Yehuda et al., 1995; Dimić et al., 2004; Žigrović, 2007; Ajduković et al., 2007.; Richardson et al., 2008). The consequences of traumatization are also evident in other aspects of mental health, primarily in the increase of depression, anxiety and addiction (Pizarro et al., 2006; Basoglu et al., 2005; De Jong et al., 2003; Johansen et al., 2007). It is therefore reasonable to expect that a higher level of traumatization would be associated with a lower quality of life (QoL). The World Health Organization defines QoL as "the individual's perception of his/her position in life in the context of the culture and value system in which he/she lives and in relation to his/her goals, expectations, standards and concerns". From the psychological view, quality of life is the result of an individual's psychological structure in interaction with the physical and social environment, based on his/ her subjective assessment (Krizmanić and Kolesarić, 1989).

There are consistent findings about the lower quality of life among traumatized people (d'Ardenne et al., 2005.; Priebe et al., 2004.; Schnurr et al., 2006; Zatzick et al., 1997; Magruder et al., 2004.; Clancy et al., 2006). If we understand the concept of quality of life as a complex subjective experience of people which depends on objective circumstances of life, personality of the individual, ways of interpretation of events, value system, and expectations (Ajduković et al., 2007), then the question is what psychological variables moderate a perception of such low quality of life in traumatized people?

Research has shown that besides the intensity and duration of exposure to traumatic experiences and consequent PTSD symptoms, variables such as personality traits, some of 
DRUŠ. ISTRAŽ. ZAGREB GOD. 20 (2011), BR. 4 (114)

STR. 1101-1118

ANTIČEVIĆ, V., KARDUM, G., BRITVIĆ, D.: WAR VETERANS'. the behavioral variables and social environment variables have major effects on the formation of physical and mental illness (Hudek-Knežević et al., 2005). Apart from examining the effects of the perception of the intensity of stress, stressful life events, and negative effects on the beginning, duration or intensity of the disease, several studies have established the relationship between coping styles and the development of mental disease in general (Folkman et al., 1986; Lazarus and Folkman, 1984; Hudek-Knežević et al., 2005; Stein et al., 2005; Howell, 2006).

Personality dimensions could be risk or protective factors in PTSD development. Personality variables and trauma intensity were found to be significant predictors of PTSD severity, accounting for $43 \%$ of the variance (Lauterbach and Vrana, 2001; Talbert et al., 1993).

The purpose of this study was to evaluate the cross-sectional differences in self-reported severity of PTSD and psychosomatic symptoms, intensity of subjective disturbance caused by lifetime exposure to traumatic events, coping styles, personality traits, and overall quality of life between the PTSD and non-PTSD Croatian War veterans. We also investigated whether it is possible to predict quality of life on the basis of PTSD and psychosomatic symptoms, coping styles and personality traits.

On the basis of previous PTSD studies we expected that war veterans with PTSD would score worse on QoL, personality and coping style questionnaires than both non-PTSD veterans and control subjects. We also expected that veterans with PTSD would score higher in psychosomatic and PTSD symptoms as well as lifetime traumatic events than subjects in the other two groups. For the non-PTSD group we expected to be similar to the control group of subjects.

\section{METHOD}

\section{Study Design and Participants}

The study was conducted in the Center for psychotrauma, Department of Psychiatry, Medical School, University of Split, Croatia, during the academic years 2008 and 2009. A total of 113 subjects within the three groups participated in the study. The first group consisted of war veterans diagnosed with PTSD $(n=40)$. The second group consisted of war veterans without a diagnosis of PTSD $(n=37)$. The third group consisted of volunteers as control subjects $(n=36)$.

Inclusion criteria for the first group were age range 35-60 years, exposure to traumatic combat experiences, and having a PTSD diagnosis. Patients with a central nervous system (CNS) 
DRUŠ. ISTRAŽ. ZAGREB GOD. 20 (2011) BR. 4 (114),

STR. $1101-1118$

ANTIČEVIĆ, V., KARDUM, G., BRITVIĆ, D.: WAR VETERANS'

\section{Instruments}

disease, addiction, acute psychotic disorder, or low intellectual abilities were excluded from the study. All participants were men.

In the second group respondents were also war participants, but without a PTSD diagnosis. Patients with a CNS disease, addiction, psychotic disorder or low intellectual abilities were excluded from this group too. The same exclusion criteria were applied during the selection of subjects for the control group, who were included only if they did not participate in the war or had a PTSD diagnosis. Participants in the first group were treated in the Center for psychotrauma and those in the other two groups were regular patients in general medicine outpatient clinics and a dental clinic.

The majority of participants in all groups had a secondary level of education. In this regard, the groups did not differ significantly $\left(\chi^{2}=0118, p=0.74\right)$.

The study included 40 PTSD veterans of an average age of 40.5 (range 33 to 51), 37 veterans of an average age of 45 (range 35 to 56), and 36 subjects in the control group of an average age of 36 (range 29 to 50). Participants with PTSD were significantly younger than veterans without PTSD $(p=0.002)$ and control subjects $(p=0.009)$, while between the latter two groups there was no significant difference $(p=0.944)$. All participants were informed about the purpose of research and gave verbal consent to participate in the study.

Life Events Checklist - LEC (Turner and Wheaton, 1995) is a 17-item measure of exposure to potentially traumatic events (PTE). The checklist assesses lifetime exposure to traumatic life events experienced, witnessed or learned about. It inquires about multiple types of exposure to each PTE. The respondents rate their experience of that event on a 5-point scale (1-"happened to me", 2-"witnessed it", 3-"learned about it", 4-"not sure", 5 -"doesn't apply"). Kappa coefficient for all items is 0.61 and the retest correlation is 0.82 . In a clinical sample of combat veterans, the LEC was significantly correlated, in the predicted directions, with measures of psychological distress and was strongly associated with PTSD symptoms (Gray et al., 2004).

For the purpose of this study, only the first point - "happened to me" - was used. Additionally, the subjects had to answer on a 3-point scale how much the event disturbed them (1-"not at all", 2-"moderately", 3-"extremely").

The Mississippi scale for combat-related posttraumatic stress disorder M-PTSD (Keane et al., 1988) is a 35-item self-report measure that assesses combat-related PTSD in veteran populations. 
DRUŠ. ISTRAŽ. ZAGREB GOD. 20 (2011), BR. 4 (114)

STR. 1101-1118

ANTIČEVIĆ, V., KARDUM, G., BRITVIĆ, D.: WAR VETERANS'.
It is designed to assess reexperiencing, avoidance and numbing, and hyperarousal symptoms associated with PTSD. Respondents are asked to rate how they feel about each item using 5-point, Likert-style response categories. Ten positively framed items are reversely scored and then responses are summed to provide an index of PTSD symptom severity which can range from 35-175. Cut off scores for a probable PTSD diagnosis have been validated for some populations, but may not generalize to other populations. For a sample of Croatian veterans, it is 106. This measure has demonstrated good test-retest reliability $(\mathrm{r}=0.97$, 1-week interval), internal consistency (alpha $=0.94)$, (Keane et al., 1988) and diagnostic accuracy (90\% diagnostic efficiency) in a sample of Vietnam combat veterans (Keane et al., 1988; Kulka et al., 1991).

The WHOQOL-BREF (WHOQoL, 1998) is a self-report scale that consists of 26 items. It is a multilingual, multicultural generic quality of life scale developed across 15 field centers. The WHOQOL-Bref includes four domains related to QoL: physical health, psychological health, social relationships and environment. The WHOQOL-Bref has been demonstrated to have satisfactory discriminant validity, internal consistency and test-retest reliability. The items are rated on a 5-point Likert scale, reflecting intensity, capacity, frequency, or evaluation. The items use questions "how much", "how completely", "how often", "how good" or "how satisfied", with possible answers ranging from "not at all satisfied" to "very satisfied". The range of scores in each domain is from 4 to 20 , whereby a higher score indicates a better QoL. The total scores on items within each domain were finally transformed on the standardized scale 0-100. High internal consistency (0.61-0.81 for all four domains) had already been established for the Croatian version of the WHOQOL-BREF in an earlier study (Skevington et al., 2004)).

The Cornell index CI (Weider et al., 1945) is a questionnaire used for quick assessment of psychosomatic problems, tendencies to anxiety, phobia, hypersensitivity, depression, obsessive-compulsive tendencies (Factor I - asthenic syndrome); cardiovascular, inhibitory and gastro-intestinal conversion, hypochondria (Factor II - conversive syndrome); impulsivity, aggression and paranoia (Factor III - sthenic syndrome). The total score on Factor I is 43, on Factor II is 38 and on Factor III 19. Only the results on Factors I and II were analyzed for the purpose of this study. CI was used for the purpose of objectification of psychological symptoms, because it has a set of control statements for assessing the subjects' understanding and tendency to simulate answers. The procedure is entirely 
DRUŠ. ISTRAŽ. ZAGREB GOD. 20 (2011) BR. 4 (114),

STR. 1101-1118

ANTIČEVIĆ, V., KARDUM, G., BRITVIC, D. WAR VETERANS' self-administered. CI consisted of 110 questions. The questions were answered by drawing a circle around either the "correct" or "incorrect" after each.

The COPE (Carver et al., 1989) is a multidimensional coping inventory to assess the different ways people respond to stress. The Croatian version of the inventory was developed and compared to the original inventory which was used as the basis for construing the new inventory, along with two scales specific for Croatian respondents. The questionnaire consists of 17 empirically derived scales that describe the three higher order factors: problem-oriented coping, emotion-oriented coping, and general disengagement (Hudek-Knežević et al., 1999). Cronbach alpha reliability coefficients for each factor are: 0.87 for problem-oriented coping, 0.92 for emotion-oriented coping; and 0.80 for disengagement (Hudek-Knežević and Kardum, 1993). Responses to individual items were scored on the 5-point Likert-type scale, whereby 1 is "never", and 5 is "always".

The Big Five Inventory (BFQ) (Caprara et al., 1993) is used for measuring the 5 -factor personality dimensions. It is a 132-item questionnaire measuring five domains (Extraversion, Agreeableness, Conscientiousness, Emotional Stability and Openness to Experience). The respondent has a 5-choice answer format that ranges from complete disagreement $(1=$ very false for me) to complete agreement ( $5=$ very true for me). Additionally, previous studies have shown that this instrument was useful for cross-language and cross-cultural research (Bennet-Martinez and John, 1998), and also it has been proven to be appropriate for measuring the 5-factor model of personality in the Croatian language (Schmitt et al., 2007). In the Croatian sample, the coefficients of internal reliability (Cronbach $\alpha$ ) ranged from 0.69 for agreeableness to 0.80 for neuroticism. Correlations between 5 personality dimensions ranged from -0.40 $(p<0.001$; between neuroticism and conscientiousness) to 0.46 ( $p<0.001$; between extraversion and openness) (Hudek-Knežević and Kardum, 2009).

\section{Statistical Analyses}

Statistica 8.0 software package (StatSoft, Inc., Tulsa, USA) was used to perform the statistical analysis of the data. Differences between categorical variables (socio-demographic, personal and behavioral characteristics) were estimated by chisquare test whereas differences among the three samples on psychological instruments and scales on continuous variables were estimated by ANOVA with Scheffe post-hoc test. Interpretation of multivariate effects of quality of life predictors was performed by forward regression analysis. Statistical values were considered significant at $p<0.05$. 


\section{RESULTS}

\section{Different Traumatic Experiences and their Subjective Disturbance}

in PTSD-, Non-PTSD Veterans, and Controls

War veterans in both groups did not differ significantly in length of stay on the battlefield $(t=0.738, p=0.463)$.

When different kinds of lifetime traumatic experiences were defined in three categories (Table 1) according to the degree of subjective disturbance (not at all, moderately disturbing, extremely disturbing), there were significant differences for five traumatic experiences separately (natural disasters, $\mathrm{p}=0.038$; traffic accidents, $\mathrm{p}=0.042$; physical or weapon attacks, $\mathrm{p}<0.001$;

$\rightarrow$ TABLE 1 Traumatic experiences across the three different subsamples (war veterans with PTSD, war veterans without PTSD, and healthy control subjects)

\begin{tabular}{|c|c|c|c|c|}
\hline & $\begin{array}{r}\text { PTSD veterans } \\
(\mathrm{n}=40)\end{array}$ & $\begin{array}{r}\text { Veterans } \\
(n=37)\end{array}$ & $\begin{array}{r}\text { Control } \\
(n=36)\end{array}$ & $\mathrm{p}^{*}$ \\
\hline \multicolumn{5}{|c|}{ Natural disaster } \\
\hline Not at all & $13(32.5)$ & $19(51.4)$ & 13 (36.1) & 0.038 \\
\hline Moderately & $13(32.5)$ & $15(40.5)$ & 17 (47.2) & \\
\hline Too much & $14(35)$ & $3(8.1)$ & $6(16.7)$ & \\
\hline \multicolumn{5}{|c|}{ Traffic accidents } \\
\hline Not at all & $13(32.5)$ & $13(35.1)$ & $14(38.9)$ & 0.042 \\
\hline Moderately & $5(12.55)$ & $14(37.8)$ & $11(30.6)$ & \\
\hline Too much & $22(55)$ & $10(27)$ & $11(30.6)$ & \\
\hline \multicolumn{5}{|c|}{ Physical or armed threat } \\
\hline Not at all & $8(20)$ & $10(27)$ & $22(61.1)$ & $<0.001$ \\
\hline Moderately & $3(7.5)$ & $14(37.8)$ & 7 (19.4) & \\
\hline Too much & $29(72.5)$ & 13 (35.1) & 7 (19.4) & \\
\hline \multicolumn{5}{|l|}{ War } \\
\hline Not at all & - & - & $26(100)$ & 0.587 \\
\hline Moderately & $3(7.5)$ & $4(13.5)$ & - & \\
\hline Too much & 37 (92.5) & $32(86.5)$ & - & \\
\hline \multicolumn{5}{|l|}{ Sudden death } \\
\hline Not at all & 7 (17.5) & $18(48.6)$ & $20(55.6)$ & 0.005 \\
\hline Moderately & $2(5)$ & $2(5.4)$ & $3(9.3)$ & \\
\hline Too much & $31(77.5)$ & 17 (45.9) & $13(36.1)$ & \\
\hline \multicolumn{5}{|c|}{ Diseases (longitudinal) } \\
\hline Not at all & $26(65)$ & 33 (89.2) & $25(69.4)$ & 0.008 \\
\hline Moderately & $2(5)$ & 0 & $6(16.7)$ & \\
\hline Too much & $12(30)$ & $4(10.8)$ & $5(13.9)$ & \\
\hline
\end{tabular}

* Chi square test

PTSD veterans were more often too much disturbed with lifetime stressful experiences (e.g. natural disasters (35\%), traffic accidents (55\%), physical or weapon attacks $(72.5 \%)$, sudden deaths $(77.5 \%)$ and diseases (30\%)) than participants in the other two groups who experienced those events more of- 
ten as moderately stressful. So, the results indicated higher vulnerability of PTSD veterans toward any kind of traumatic events.

As can be expected, the majority of the participants in both veterans groups considered combat exposures as the most stressful life experiences among all others $(p=0.587)$.

\section{Differences in Clinical Characteristics, Coping Styles and Personality Traits}

PTSD veterans had the highest average score (136.6 \pm 17.66$)$ on the M-PTSD scale and the result was above the cut-off score (106). Close to the value of the cut-off score was the result of

(1) TABLE 2

Differences among three samples (ANOVA) on psychological instruments and scales non-PTSD veterans $(98.2 \pm 23.55)$, and the result of the control group on this scale was much lower $(80.2 \pm 18.46)$. There was a statistically significant difference $(\mathrm{p}<0.001)$ between all groups (Table 2).

\begin{tabular}{|c|c|c|c|c|c|}
\hline Psychological instrument & $\begin{array}{r}\text { PTSD } \\
\text { veterans } \\
(\text { mean } \pm \text { SD })\end{array}$ & $\begin{array}{r}\text { Non-PTSD } \\
\text { veterans } \\
\text { (mean } \pm S D)\end{array}$ & $\begin{array}{r}\text { Control } \\
\text { subjects } \\
\text { (mean } \pm S D)\end{array}$ & $\mathrm{F}$ & $\mathrm{p}$ \\
\hline M-PTSD & $136.6 \pm 17.66$ & $98.2 \pm 23.55$ & $80.2 \pm 18.46$ & 79.26 & $<0.001^{\mathrm{a}}$ \\
\hline COPE (Problem oriented) & $57.4 \pm 10.63$ & $62.2 \pm 10.33$ & $64.2 \pm 8.14$ & 4.93 & $0.009 \mathrm{~b}$ \\
\hline COPE (Emotion oriented) & $23.6 \pm 6.45$ & $28.4 \pm 7.10$ & $29.0 \pm 8.65$ & 6.17 & $0.003^{c}$ \\
\hline COPE (Avoiding) & $105.9 \pm 14.58$ & $92.5 \pm 18.41$ & $85.1 \pm 12.58$ & 18.00 & $<0.001^{\mathrm{d}}$ \\
\hline Cornell index (Conversion) & $19.0 \pm 8.93$ & $8.9 \pm 7.66$ & $4.6 \pm 6.36$ & 35.09 & $<0.001 \mathrm{e}$ \\
\hline Cornell index (Anxious/Depression) & $26.1 \pm 7.95$ & $12.5 \pm 9.96$ & $7.5 \pm 6.80$ & 51.38 & $<0.001^{\mathrm{f}}$ \\
\hline BF - Extraversion* & $44.5 \pm 13.61$ & $55.7 \pm 11.24$ & $55.8 \pm 9.65$ & 11.95 & $<0.001 \mathrm{~g}$ \\
\hline BF - Agreeableness & $49.7 \pm 16.82$ & $61.0 \pm 15.03$ & $65.6 \pm 11.35$ & 11.93 & $<0.001^{\mathrm{h}}$ \\
\hline $\mathrm{BF}$ - Conscientiousness & $56.6 \pm 15.58$ & $60.8 \pm 12.57$ & $63.2 \pm 10.35$ & 2.47 & 0.089 \\
\hline BF - Neuroticism & $47.1 \pm 12.93$ & $63.6 \pm 11.81$ & $61.2 \pm 11.71$ & 20.86 & $<0.001^{\mathrm{i}}$ \\
\hline BF - Openness & $43.7 \pm 13.41$ & $54.9 \pm 14.59$ & $54.7 \pm 13.26$ & 8.42 & $<0.001 j$ \\
\hline
\end{tabular}

* Scales from Big Five questionnaire

a Scheffe test for post hoc analysis showed that PTSD veterans had higher score than Non-PTSD veterans $(p<0.01)$ and control subjects $(p<0.01)$

b PTSD veterans had significant lower score than control subjects $(\mathrm{p}<0.01)$. There was no significant difference between PTSD veterans and Non-PTSD veterans $(p=0.106)$ and between Non-PTSD veterans and control subjects $(p=0.669)$

c PTSD veterans had significant lower score than Non-PTSD veterans $(p=0.021)$ and control subjects $(\mathrm{p}<0.01)$. There was no significant difference between Non-PTSD veterans and control subjects $(\mathrm{p}=0.933)$

d PTSD veterans had significant higher score than Non-PTSD veterans $(p<0.01)$ and control subjects $(\mathrm{p}<0.01)$. There was no significant difference between Non-PTSD veterans and control subjects $(\mathrm{p}=0.126)$

e PTSD veterans had significant higher score than Non-PTSD veterans $(p<0.01)$ and control subjects $(\mathrm{p}<0.01)$. There was no significant difference between Non-PTSD veterans and control subjects $(\mathrm{p}=0.062)$

f Post hoc analysis showed that PTSD veterans had higher score than Non-PTSD veterans $(p<0.01)$ and control subjects $(p<0.01)$. There was significant difference between Non-PTSD veterans and control subjects $(p=0.042)$ 
g PTSD veterans had significant lower score than Non-PTSD veterans $(\mathrm{p}<0.01)$ and control subjects $(\mathrm{p}<0.01)$. There was no significant difference between Non-PTSD veterans and control subjects $(\mathrm{p}=0.999)$

h PTSD veterans had significant lower score than Non-PTSD veterans $(p<0.01)$ and control subjects $(\mathrm{p}<0.01)$. There was no significant difference between Non-PTSD veterans and control subjects $(\mathrm{p}=0.413)$

i PTSD veterans had significant lower score than Non-PTSD veterans $(p<0.01)$ and control subjects $(p<0.01)$. There was no significant difference between Non-PTSD veterans and control subjects $(\mathrm{p}=0.697)$

j PTSD veterans had significant lower score than Non-PTSD veterans $(p<0.01)$ and control subjects $(\mathrm{p}<0.01)$. There was no significant difference between Non-PTSD veterans and control subjects $(\mathrm{p}=0.999)$

The significant differences between groups were obtained on three COPE Questionnaire scales (active coping, $\mathrm{p}=0.009$; emotional coping $\mathrm{p}=0.003$; and avoidance, $\mathrm{p}<0.001)$. The PTSD veterans were less capable of dealing actively and emotionally with stress, and more often tended to avoid all stressful situations perceived potentially threatening to themselves than the non-PTSD veterans and controls.

The differences were also obtained on both anxious-depressive $(p<0.001)$ and conversion symptoms $(p<0.001) C I$ scales. Compared to the controls, all veterans had more anxious-depressive and conversive (gastrointestinal, cardiologic and neurologic) symptoms. The symptoms were more pronounced in PTSD veterans than in the non-PTSD subjects.

The personality questionnaire results indicated higher Introversion and Emotional Instability of the PTSD veterans, compared to the other two groups. Statistically significant differences were found on those scales between all groups $(p<0.001$, separately). Similarly, on the Agreeableness and Openness scales the results across the three groups differed significantly (both $\mathrm{p}<0.001$, separately). PTSD veterans also scored higher than the subjects in other two groups. Only on the variable of Conscientiousness there was no significant difference between the veterans and control group $(\mathrm{p}=0.089)$.

There was statistical difference among the PTSD veterans, veterans and control in their scores on physical QoL $(\mathrm{F}=37.42$, $\mathrm{p}<0.001)$, psychological QoL $(\mathrm{F}=32.35, \mathrm{p}<0.001)$, social relationships QoL $(\mathrm{F}=22.41, \mathrm{p}<0.001)$, and level of social security QoL $(\mathrm{F}=21.99$, $\mathrm{p}<0.001)$.

As can be seen from Figure 1, the control subjects had a better quality of physical $(p<0.001)$ and mental health $(p<0.001)$, better quality of social relations $(p<0.001)$, and felt safer in the broad environment $(\mathrm{p}<0.001)$ than both PTSD veterans. The control subjects had a better quality of physical health $(\mathrm{p}<0.05)$ and felt safer in the broad environment $(p<0.05)$ than non PTSD veterans but there was no statistical difference on mental health 
(1) FIGURE 1

Quality of life among PTSD, veterans, and control group $(p=0.207)$ and quality of social relations $(p=0.140)$. Nevertheless, PTSD veterans scored even lower than non-PTSD veterans in all QoL domains $(p<0.01)$.

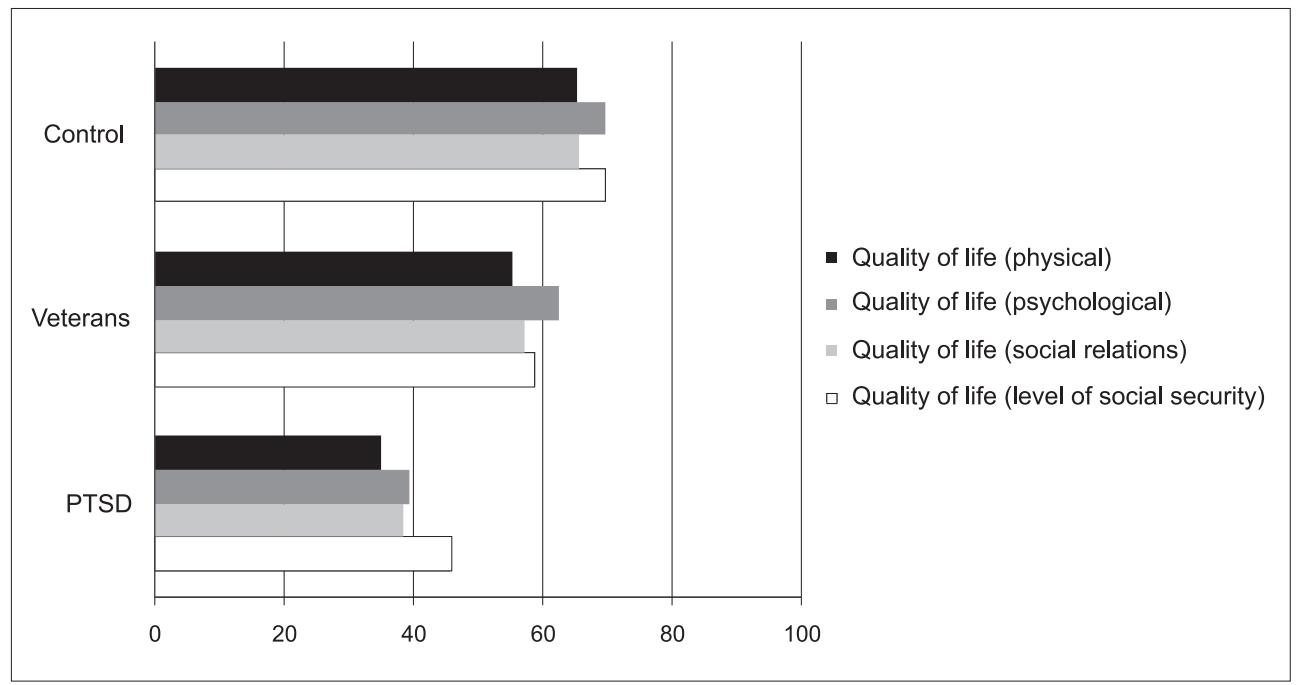

A regression analysis for quality of life as criterion obtained the multiple correlation coefficient of 0.856 , thus explaining $72.5 \%$ of the total variance in the criterion, which proved statistically significant $(\mathrm{p}<0.01)$ (Table 3$)$.

Q TABLE 3 predictors through forward regression analysis

\begin{tabular}{lrrrr}
\hline Psychological instrument & B & Beta & $\mathrm{t}$ & $\mathrm{p}$ \\
\hline M-PTSD & -1.97 & -0.83 & -15.3 & $<0.001$ \\
COPE (Active) & 0.96 & 0.13 & 2.4 & 0.017 \\
COPE (Emotional) & & & 0.8 & 0.420 \\
COPE (Avoiding) & & & -1.1 & 0.263 \\
Cornell index (Conversion) & & & -1.4 & 0.168 \\
Cornell index (Anxious/Depression) & & -0.72 & 0.471 \\
BF - Extraversion* & 1.14 & 0.19 & 3.5 & 0.001 \\
BF - Agreeableness & & & 1.68 & 0.096 \\
BF - Conscientiousness & & & 0.15 & 0.882 \\
BF - Neuroticism & & & -1.9 & 0.066 \\
R=0.856; R2=0.732; F=98.348; df=3; $\mathrm{p}<0.001$ & & &
\end{tabular}

* Scales from Big Five questionnaire

Intensity of PTSD, extraversion and active coping were individually significant in explaining the total QoL $(p<0.01)$. The highest relative contribution was that of the intensity of PTSD variable $(\beta=-0.83, p<0.001)$, whereas the variables of extraversion $(\beta=0.19, \mathrm{p}=0.001)$ and active coping $(\beta=0.13, \mathrm{p}=0.017)$ contributed much lesser. Although the variables of agreeableness $(\beta=0.11, p=0.096)$ and emotional stability $(\beta=-0.11, p=0.066)$ were left out of the further prediction in the third-step for- 
ward regression, their results were marginally significant and should therefore be considered in the interpretation of findings.

\section{DISCUSSION}

This study showed that veterans with PTSD assessed not only combat experiences, but also exposure to natural disasters, traffic accidents, physical and armed threats, sudden deaths and severe illnesses as extremely stressful, much more so than veterans without PTSD or control subjects. As could be expected, PTSD veterans were more likely to have clinically significant symptoms of the disorder. Veterans with PTSD less frequently used active and emotional coping with stressful lifetime events, and more often avoid facing stressful events.

In a retrospective study, Clancy et al. (2006) found that age, greater combat exposure, and premilitary and postmilitary traumas are associated with increased PTSD symptomatology. Stein et al. (2005), found that lifetime trauma, combat exposure, and avoidant coping were strongly related to PTSD symptoms. On a sample of 250 firefighters from Kentucky, significant effects were found for ineffective coping skills ("Avoidance Coping") and general self-efficacy on the levels of PTSD.

Also, ineffective coping skills predicted higher levels of PTSD (Howell, 2006). Avoidant coping was characterized by behavioral disengagement, substance use, self-distraction, denial, and self-blame (Howell, 2006). Our findings on the scale of psychosomatic symptoms point into the same direction: PTSD veterans more often suffered from anxiety-depressive and conversive disorders in different somatic systems.

All domains of the quality of life (physical and mental health, quality of social relationships, and environmental safety) were rated lower by the PTSD veterans than the control subjects. Exploring the quality of life of people suffering from PTSD, d'Ardenne et al. (2005) have also found that QoL in people suffering from PTSD was worse than in the comparison group. Worse quality of life contributed to the pronounced depression and anxiety and avoidance symptoms. In the same study it was found that older age and ethnic minority background were risk factors for worse quality of life. Priebe et al. (2004) showed that people who have sought psychiatric help and had more posttraumatic, depressive, and anxiety disturbances had also a poorer quality of life. Several studies of Vietnam veterans examined the impact of PTSD on QoL using a wide range of measures and showed that PTSD negatively affected QoL in both females and males (Schnurr et al., 2006; Zatzick et al., 1997; Magruder et al., 2004).

Regarding the personality traits, PTSD veterans were less extravert and agreeable in contacts, and more emotionally un- 
DRUŠ. ISTRAŽ. ZAGREB GOD. 20 (2011) BR. 4 (114),

STR. 1101-1118

ANTIČEVIĆ, V., KARDUM, G., BRITVIĆ, D. WAR VETERANS' stable and closed towards new experiences than the other two groups of participants in our study. Findings of previous studies indicate that neuroticism interacts with trauma intensity in predicting PTSD severity. Among persons low in neuroticism, a modest trauma intensity-PTSD relationship has been found, whereas this relationship was strong among persons high in neuroticism (Leuterbach and Vrana, 2001). A normative NEO-PI profile for persons diagnosed with combat-related PTSD (Vietnam veterans) is characterized by an extremely high neuroticism score and an extremely low agreeableness score (Talbert et al., 1993).

The level of intensity of PTSD symptoms was the most important predictor of the quality of life among veterans: a subjective assessment of QoL in all domains decreases with the increase of intensity of PTSD. Active coping with stress predicts better quality of life: people who successfully identify and resolve problems in life seem to be more satisfied with their health and social relationships, and they generally feel more confident in life and their environment. Among personality traits, only extraversion was found to be a significant predictor of QoL, whereas agreeableness and emotional stability were marginally significant.

Results of non-PTSD veterans showed a more efficient coping, lower intensity of PTSD, less frequent psychosomatic disorders, and more stable personality traits than the PTSD veterans. QoL in all domains was rated better by non-PTSD than PTSD veterans.

Richardson et al. (2008) found that veterans with PTSD have significant impairments in mental and physical health-related quality of life (HRQoL). Mental HRQoL was significantly lower for peacemakers with, than without, PTSD. Yehuda et al. (1995) found that survivors with PTSD reported significantly greater cumulative trauma and recent stress than survivors without PTSD and comparison subjects.

Dimić et al. (2004) investigated 274 patients who have experienced multiple severe war-related traumas as civilians or soldiers. A significant difference between the PTSD and non-PTSD groups was identified on NEO-PI-R personality scales defined as neuroticism, as well as on the following MCMI dimensions: avoidant, dependant, borderline, and paranoid.

Croatian quality of life research in war participants found the lowest quality of life in psychiatrically treated war veterans with PTSD compared to civilians who have experienced war trauma but have not sought professional help (Zigrović, 2007).

Similarly, on a representative sample of 454 traumatized war participants Ajduković et al. (2007) have found significantly higher quality of life in persons without mental disorders compared to those with PTSD and depression. 
DRUŠ. ISTRAŽ. ZAGREB GOD. 20 (2011), BR. 4 (114)

STR. 1101-1118

ANTIČEVIĆ, V., KARDUM, G., BRITVIĆ, D.: WAR VETERANS'..

Regarding sensitivity to stress, non-PTSD veterans were not different from control subjects, except in cases of physical or armed threat, which veterans judged highly disturbing. They were also similar to control subjects with regard to personality traits. However, non-PTSD veterans had much more pronounced symptoms of PTSD, more frequent psychosomatic symptoms and a poorer quality of life in all domains. This finding supports the hypothesis of partial PTSD that does not meet the criteria for diagnosis of the disorder, but still proves that exposure to war traumas negatively affects social adaptation. It is possible that even before war exposure non-PTSD veterans had a more stable personality structure than PTSD veterans, so the war trauma was less disruptive to their functioning, but still negatively affected their mental and physical health and the quality of life in general. Another possible explanation relates to the chronological age of the two groups of veterans. PTSD veterans were younger than non-PTSD veterans at the time of war, and it is possible that younger age was a risk factor for the development of PTSD.

The contribution of this study relates to the investigation of war participants who did not develop PTSD, but were exposed equally long to armed conflict as PTSD veterans. Comparisons between the groups showed that although non-PTSD veterans did not have clinically significant psychiatric symptoms, they still experienced a deterioration of psychosomatic functioning and quality of life in general.

The limitations of the study relate to a relatively small number of participants and the age differences between the PTSD and non-PTSD group. The study was further limited by the fact that it did not collect data about different kinds of war traumatic events because it had been showed in earlier work that characteristics of the individual as well as of the event contribute to understanding short- and long-term outcomes (King et al., 1998). Also, the data from this study were cross-sectional. Thus, we cannot ascertain any cause and effect relationships between lifetime exposure to traumatic events and actual psychological characteristics of the subjects based on the present research.

\section{REFERENCES}

Ajduković, D., Kraljević, R. and Penić, S. (2007), Kvaliteta života osoba pogođenih ratom. Ljetopis socijalnog rada, 14 (3): 505-526.

Basoglu, M., Livanou, M., Crnobarić, C., Frančišković, T., Suljić, E., Đurić, D. and Vranešić, M. (2005), Psychiatric and Cognitive Effects of War in Former Yugoslavia. Journal of American Medical Association, 294 (5): 580-590. doi:10.1001/jama.294.5.580

Benet-Martínez, V. and John, O. P. (1998), Los Cinco Grandes across Cultures and Ethnic Groups: Multitrait-Multimethod Analyses of the Big Five in Spanish and English. Journal of Personality and Social Psychology, 75 (3): 729-750. doi:10.1037//0022-3514.75.3.729 
DRUŠ. ISTRAŽ. ZAGREB GOD. 20 (2011) BR. 4 (114),

STR. $1101-1118$

ANTIČEVIĆ, V., KARDUM, G., BRITVIĆ, D.: WAR VETERANS'.
Caprara, G. V., Barbaranelli, C., Borgogni, L. and Perugini, M. (1993), The "Big Five Questionnaire": A New Questionnaire to Assess the Five Factor Model. Personality and Individual Differences, 15 (3): 281-288. doi:10. 1016/0191-8869(93)90218-R

Carver, C. S., Scheier, M. F. and Weintraub, J. K. (1989), Assessing Coping Strategies: A Theoretically Based Approach. Journal of Personality and Social Psychology, 56 (2): 267-283. doi:10.1037//0022-3514.56.2.267

Clancy, C. P., Graybeal, A., Tompson, W. P., Badgett, K. S., Feldman, M. E., Calhoun, P. S., Erkanli, A., Hertzberg, M. A. and Beckham, J. C. (2006), Lifetime Trauma Exposure in Veterans with Military-Related Posttraumatic Stress Disorder: Association with Current Symptomatology. Journal of Clinical Psychiatry, 67 (9): 1346-1353. doi:10.4088/JCP.v 67n0904

D'Ardenne, P., Capuzzo, N., Fakhoury, W. K. H., Janković-Gavrilović, J. and Priebe, S. (2005), Subjective Quality of Life and Posttraumatic Stress Disorder. The Journal of Nervous and Mental Disease, 193 (1): 62-65.

De Jong, J. T., Komproe, I. H. and Van Ommeren, M. (2003), Common Mental Disorders in Postconflict Settings. Lancet, 361 (9375): 2128-2130.

Dimić, S., Lecić-Toševski, D. and Gavrilović-Janković, J. (2004), The Relationship between Personality Dimensions and Posttraumatic Stress Disorder. Psihijatrija danas (Psychiatry Today), 36 (1): 39-50.

Folkman, S., Lazarus, R. S., Gruen, R. J. and DeLongis, A. (1986), Appraisal, Health Status, and Psychological Symptoms. Journal of Personality and Social Psychology, 50 (3): 571-579. doi:10.1037//0022-3514.50.3.571

Gray, M. J., Litz, B. T., Hsu, J. L. and Lombardo, T. W. (2004), Psychometric Properties of the Life Events Checklist. Assessment, 11 (4): 330-341. doi:10.1177/1073191104269954

Howell, P. M. (2006), Once More into the Breach: Effective Leadership, Coping Skills, and Self-Efficacy as Mediators between Traumatic Experiences and the Development of PTSD in Firefighters [dissertation].

Hudek-Knežević, J. and Kardum, I. (1993.), Upitnik dispozicijskog i situacijskog suočavanja sa stresom i njegove psihometrijske značajke. Godišnjak zavoda za psihologiju, 2: 43-63.

Hudek-Knežević, J., Kardum, I. and Vukmirović, Ž. (1999), The Structure of Coping Styles: A Comparative Study of Croatian Sample. European Journal of Personality, 13 (2): 149-161.

Hudek-Knežević, J., Kardum, I. and Kalebić Maglica, B. (2005), The Sources of Stress and Coping Styles as Mediators and Moderators of the Relationship between Personality Traits and Physical Symptoms. Review of Psychology, 12 (2): 91-101.

Hudek-Knežević, J. and Kardum, I. (2009), Five-Factor Personality Dimensions and 3 Health-Related Personality Constructs as Predictors of Health. Croatian Medical Journal, 50 (4): 394-402. doi:10.3325/ cmj.2009.50.394

Johansen, V. A., Wahl, A. K., Eilertsen, D. E., Weisaeth, L. and Hanestad, B. R. (2007), The Predictive Value of Post-Traumatic Stress Disorder Symptoms for Quality of Life: A Longitudinal Study of Physically Injured Victims of Non-Domestic Violence. Health and Quality of Life Outcomes, 5: 26. doi:10.1186/1477-7525-5-26 
DRUŠ. ISTRAŽ. ZAGREB GOD. 20 (2011), BR. 4 (114) STR. 1101-1118

ANTIČEVIĆ, V., KARDUM, G., BRITVIĆ, D.: WAR VETERANS'..
Keane, T. M., Caddell, J. M. and Taylor, K. L. (1988), Mississippi Scale for Combat-Related Posttraumatic Stress Disorder: Three Studies in Reliability and Validity. Journal of Consulting and Clinical Psychology, 56 (1): 85-90. doi:10.1037//0022-006X.56.1.85

Kilpatrick, D. G. and Acierno, R. (2003), Mental Health Needs of Crime Victims: Epidemiology and Outcomes. Journal of Traumatic Stress, 16 (2): 119-132. doi:10.1023/A:1022891005388

King, L. A., King, D. W., Fairbank, J. A., Keane, T. M. and Adams, G. A. (1998), Resilience-Recovery Factors in Post-Traumatic Stress Disorder among Female and Male Vietnam Veterans: Hardiness, Postwar Social Support, and Additional Stressful Life Events. Journal of Personality and Social Psychology, 74 (2): 420-434. doi:10.1037//00223514.74.2.420

Krizmanić, M. and Kolesarić, V. (1989), Pokušaj konceptualizacije pojma "kvaliteta života". Primijenjena psihologija, 10 (3): 179-184.

Kulka, A., Schlenger, W. E., Fairbank, J. A., Jordan, B. K., Hough, R. L., Marmar, C. R. and Weiss, D. S. (1991), Assessment of Posttraumatic Stress Disorder in the Community: Prospects and Pitfalls from Recent Studies of Vietnam Veterans. Journal of Consulting and Clinical Psychology, 3 (4): 547-560. doi:10.1037//1040-3590.3.4.547

Lauterbach, D. and Vrana, S. R. (2001), The Relationship among Personality Variables, Exposure to Traumatic Events, and Severity of Posttraumatic Stress Symptoms. Journal of Traumatic Stress, 14 (1): 29-45. doi:10.1023/A:1007831430706

Lazarus, R. S. and Folkman, S. (1984), Stress, Appraisal, and Coping, New York, Springer Publishing Company.

Magruder, K. M., Frueh, B. C., Knapp, R. G., Johnson, M. R., Vaughan, J. A., Carson, T. C., Powell, D. A. and Hebert, R. (2004), PTSD Symptoms, Demographic Characteristics, and Functional Status among Veterans Treated in VA Primary Care Clinics. Journal of Traumatic Stress, 17 (4): 293-301. doi:10.1023/B:JOTS.0000038477.47249.c8

Pizarro, J., Silver, C. and Prause, J. A. (2006), Physical and Mental Health Costs of Traumatic War Experiences among Civil War Veterans. Archives of General Psychiatry, 63 (2): 193-200. doi:10.1001/archpsyc.63.2.193

Priebe, S., Janković-Gavrilović J., Schützwohl, M., Galeazzi Gian, M., Lečić-Toševski, D., Ajduković, D., Frančišković, T., Kučukalić, A. and Popovski, M. (2004), Studija o dugotrajnim kliničkim i socijalnim posledicama posle ratnih iskustava u bivšoj Jugoslaviji - metod 'Connect' projekta. (Study of Long Term Clinical and Social Outcomes After War Experience in Ex Yugoslavia - Methods of the "Connect Project"). Psihijatrija danas, 36 (1): 101-110.

Richardson, J. D., Long, M. E., Pedlar, D. and Elhai, J. D. (2008), Posttraumatic Stress Disorder and Health-Related Quality of Life among a Sample of Treatment - and Pension-Seeking Deployed Canadian Forces Peacekeeping Veterans. Canadian Journal of Psychiatry, 53 (9): 594-600.

Schmitt, D. P., Allik J., McCrae, R. R., Benet-Martinez, V., Alcalay, L., Ault, L., et al. (2007), The Geographic Distribution of Big Five Personality Traits: Patterns and Profiles of Human Self-Description Across 56 Nations. Journal of Cross-Cultural Psychology, 38 (2): 173-212. doi:10.1177/0022022106297299 
DRUŠ. ISTRAŽ. ZAGREB GOD. 20 (2011), BR. 4 (114),

STR. 1101-1118

ANTIČEVIĆ, V., KARDUM, G., BRITVIĆ, D.: WAR VETERANS'...
Schnurr, P. P., Hayes, A. F., Lunney, C. A., McFall, M. and Uddo, M. (2006), Longitudinal Analysis of the Relationship between Symptoms and Quality of Life in Veterans Treated for Posttraumatic Stress Disorder. Journal of Consulting and Clinical Psychology, 74 (4): 707-713. doi:10.1037/0022-006X.74.4.707

Skevington, S. M., Lotfy, M. and O'Connell, K. A. (2004), The World Health Organization's WHOQOL-BREF Quality of Life Assessment: Psychometric Properties and Results of the International Field Trial. A Report from the WHOQOL Group. Quality of Life Research, 13 (2): 299-310. doi:10.1023/B:QURE.0000018486.91360.00

Stein, A. L., Tran, G. Q., Lund, L. M., Haji, U., Dashevsky, B. A. and Baker, D. G. (2005), Correlates for Posttraumatic Stress Disorder in Gulf War Veterans: A Retrospective Study of Main and Moderating Effects. Journal of Anxiety Disorders, 19 (8): 861-876. doi:10.1016/j.janxdis. 2004.09.006

Talbert, F. S., Braswell, L. C., Albrecht, J. W., Hyer, L. A. and Boudewyns, P. A. (1993), NEO-PI Profiles in PTSD as a Function of Trauma Level. Journal of Clinical Psychology, 49 (5): 663-669. doi:10.1002/10974679(199309)49:5<663::AID-JCLP2270490508>3.0.CO;2-A

Turner, R. and Wheaton, B. (1995), Checklist Measurement of Stressful Life Events. In: S. Cohen, R., Kessler, L. Gordon (Eds.), Measuring Stress: A Guide for Health and Social Scientists (pp. 29-59), New York, Oxford University Press.

Weider, A., Brodman, K., Mittelmann, B., Wechsler, D. and Wolff, H. G. (1945), The Cornell Service Index: A Method for Quickly Assaying Personality and Psychosomatic Disturbances in Men in the Armed Forces. War Medicine, 7: 209.

WHOQoL (1998), Development of the World Health Organisation WHOQoL-BREF Quality of Life Assessment. The WHOQOL Group. Psychological Medicine, 28 (3): 551-558.

Yehuda, R., Kahana, B., Schmeidler, J., Southwick, S. M., Wilson, S. and Giller, E. L.(1995), Impact of Cumulative Lifetime Trauma and Recent Stress on Current Posttraumatic Stress Disorder Symptoms in Holocaust Survivors. American Journal of Psychiatry, 152 (12): 1815-1818.

Zatzick, D. F., Marmar, C. R., Weiss, D. S., Browner, W. S., Metzler, T. J., Golding, J. M., Stewart, A., Schlenger, W. E. and Wells, K. B. (1997), Posttraumatic Stress Disorder and Functioning and Quality of Life Outcomes in a Nationally Representative Sample of Male Vietnam Veterans. American Journal of Psychiatry, 154 (12): 1690-1695.

Žigrović, L. (2007), Psihometrijska validacija upitnika kvalitete života MANSA, Diplomski rad, Zagreb, Filozofski fakultet, Odsjek za psihologiju. 
DRUŠ. ISTRAŽ. ZAGREB GOD. 20 (2011), BR. $4(114)$

STR. 1101-1118

ANTIČEVIĆ, V., KARDUM, G., BRITVIĆ, D.: WAR VETERANS'.
Utjecaj traumatskih životnih iskustava, psihičkoga i fizičkoga zdravlja na kvalitetu života hrvatskih branitelja

Vesna ANTIČEVIĆ

KBC Split, Split

Goran KARDUM

Filozofski fakultet, Split

Dolores BRITVIĆ

KBC Split, Split

U ovom istraživanju ispitivane su razlike u psihičkim simptomima, izloženosti traumatskim događajima tijekom života, stilovima suočavanja, osobinama ličnosti i ukupnoj kvaliteti života između hrvatskih branitelja koji su oboljeli od PTSP-a i branitelja bez PTSP-a. U istraživanju su sudjelovale tri skupine ispitanika (branitelii sa PTSP-om, branitelii bez PTSP-a i kontrola). Branitelii sa PTSP-om procjenjuju borbena iskustva i izloženost drugim životnim traumatskim događajima kao vrlo stresne, u mnogo većoj mieri nego veterani bez PTSP-a ili kontrolni ispitanici. Rezultati branitelia bez PTSP-a slični su rezultatima ispitanika iz kontrolne skupine, osim na M-PTSD upitniku, skali psihosomatskih simptoma i skali suočavanja izbjegavanjem. Intenzitet PTSP-a, ekstraverzija i aktivno suočavanje pojedinačno su značajni u objašnjavanju ukupne kvalitete života $(p<0,01)$. Ovo istraživanje upućuje na pojačanu osjetliivost branitelja sa PTSP-om na životne traumatske događaje nakon izloženosti traumatskim ratnim iskustvima u odnosu na branitelje bez PTSP-a.

Ključne riječi: PTSP, ličnost, kvaliteta života

\section{Die Auswirkung traumatischer Lebenserfahrungen, der körperlichen und der seelischen Gesundheit auf die Lebensqualität kroatischer Kriegsteilnehmer}

\author{
Vesna ANTIČEVIĆ \\ Klinikzentrum Split, Split \\ Goran KARDUM \\ Philosophische Fakultät, Split \\ Dolores BRITVIĆ \\ Klinikzentrum Split, Split
}

Die Verfasser hinterfragen in ihrer Untersuchung, wie sich ehemalige kroatische Kriegsteilnehmer, die an einer PTBS (Posttraumatischen Belastungsstörung) erkrankt sind, unterscheiden von solchen, denen eine solche Erkrankung 
DRUŠ. ISTRAŽ. ZAGREB GOD. 20 (2011) BR. 4 (114)

STR. $1101-1118$

ANTIČEVIĆ, V., KARDUM, G., BRITVIĆ, D. WAR VETERANS' erspart geblieben ist. Untersucht wird, inwiefern die Befragten psychische Auffälligkeiten vorweisen, ob sie traumatischen Erlebnissen ausgesetzt waren, wie sie damit umgingen, welche Persönlichkeitsmerkmale sie besitzen und welche Lebensqualität ihr Dasein hat. An der Untersuchung nahmen ehemalige Kriegsteilnehmer mit einer PTBS teil, ferner gesunde Kriegsteilnehmer sowie eine Kontrollgruppe. Die erkrankten Untersuchungsteilnehmer bezeichneten die erlebten Kampfhandlungen und andere traumatische Erlebnisse als außerordentlich belastend und weitaus stressiger, als gesunde Kriegsteilnehmer oder Mitglieder der Kontrollgruppe es in Erinnerung hatten. Die Ergebnisse der Untersuchungsteilnehmer ohne PTBS ähneln jenen der Kontrollgruppe; Ausnahmen sind der M-PTBS-Fragebogen, eine Skala zur Ermittlung von psychosomatischen Symptomen und eine weitere zur Ermittlung von Stressbewältigungsstrategien. Die Intensität der PTBS, Extraversion und aktive Stressbewältigung können im Einzelfall wesentlich dazu beitragen, die Lebensqualität insgesamt zu bewerten $(p<0,01)$. Die vorliegende Untersuchung verweist darauf, dass ehemalige Kriegsteilnehmer, die an einer PTBS erkrankt sind, mit gesteigerter Empfindlichkeit auf traumatische Ereignisse nach den durchlebten Kriegstagen reagieren - stärker als Kriegsteilnehmer ohne PTBS.

Schlüsselbegriffe: Posttraumatische Belastungsstörung (PTBS), Persönlichkeit, Lebensqualität 